\title{
WORK-LIFE BALANCE AND THE LEGAL RIGHT TO REQUEST FLEXIBLE WORKING ARRANGEMENTS

\author{
Lisa Dancaster
} \\ School of Management, University of Kwa-ZuluNatal
}

\begin{abstract}
In 2003, eligible employees in the United Kingdom acquired the legal right to request flexible working arrangements. The government believes that this new right will provide parents with greater choice and support in balancing work and childcare, whilst being compatible with business efficiency. This article critically appraises this new right and examines how it is applied in relation to other UK legislation on discrimination and unfair dismissal. An overview of international studies on corporate efforts to introduce family-friendly arrangements, and an overview of governmental efforts to address the reconciliation of work and family-life is provided in this article, with a view to arguing that there is a need, in South Africa, for state policy regarding work-life balance and for further research into corporate efforts to introduce family-friendly work arrangements.
\end{abstract}

JEL J81, J83

\section{1}

\section{Introduction}

Work-life balance is not a side issue, but a central issue in $21^{\text {st }}$ century societies. There is an increase in female participation in the workforce, greater diversity than the traditional single breadwinner and a homemaker per household, increased dissatisfaction with long working hours intruding on family life, a more dynamic work/life cycle and increased awareness of the negative effects of economic determinism on happiness and well-being (Thompson, 2003: 1805).

For working mothers, the choices regarding labour market participation are influenced by the institutional structures that do or do not support the combination of motherhood, paid work and other career prerogatives.

A study of legal entitlements related to workfamily arrangements in European Union countries focused on the following four measures (Koopmans \& Schippers, 2003: 7):

a) Leave schemes, including maternity leave, paternity leave, parental leave, childcare leave, childbirth and related leave; b) Flexible working arrangements (FWAs); including part-time work, job sharing, flexible working time including compressed workday, flexitime workweek, teleworking and working from home;

c) Tax systems and financial support for families; and

d) Childcare facilities.

Institutional theory is based on the assumption that institutional pressure, through public awareness and state regulations, influences employers to develop work-family arrangements (Di Maggio \& Powell,1983) ${ }^{1}$. Recent UK legislative amendments, giving eligible employees the right to request flexible working arrangements from their employer, are in keeping with this theory. This article will critically examine these amendments and also address how this right works with other UK legislation such as the Sex Discrimination Act.

In order to view the legislation in the context of work-life balance, this article will also address some of the results of research into the adoption of family-friendly policies (which include the introduction of flexible working arrangements). 
Finally, an overview of policy considerations in other countries towards the reconciliation of work and family life is given with a view to suggesting that there is an urgent need to address the issue of work-personal life integration in South Africa, both at policy level and through further research into what is being offered by South African employers.

\section{2}

\section{The right to request flexible working arrangements (FWAs) in UK law}

\subsection{The eligibility to request FWAs}

On the 6 April 2003 a new legal framework for dealing with flexible working requests from qualifying parents came into force ${ }^{2}$.

Following a set procedure (see below), eligible employees have a right to request flexible working arrangements. Their employers have no obligation to accede to the request but must, in accordance with a set procedure, meet with the employee, give due consideration to the request, and only refuse it on specified grounds.

In order to make a request an employee (male or female) must:

- be an employee;

- have worked for their employer continuously for at least 26 weeks at the date of application;

- be either the mother, father, adopter, guardian or foster parent of the child or married to, or partner of one of the above and have or expect to have responsibility for the upbringing of the child.

The qualifying employee must make the application to his/her employer before their child turns six or, if disabled, eighteen and must not have made an application in the previous twelve months.

After this age, the employee loses the statutory right to request flexible working.

This is seen as a major flaw in the provisions. It fails to accommodate changing circumstances affecting parental responsibilities, such as death, special needs of a child short of disability or divorce that may arise after the time to make a request (Williams, 2003: 288).

Although an applicant could theoretically make a request before the child's sixth birthday to be effective some time after this point, employees are unlikely to have the gift of foresight and would not wish to commit themselves to a permanent alteration in their contractual terms to cater for such remote possibilities (Williams, 2003: 188).

\subsection{The nature of the contract variation and grounds for refusal}

The request for a change to conditions of employment must relate to:

- the hours an employee is required to work;

- the times an employee is required to work;

- where, as between his/her home and business, an employee is required to work; or

- such other aspect of the terms and conditions of employment as the Secretary of State may specify by regulations.

This provision is broadly worded and would cover such FWAs as compressed working weeks, job sharing, flexi-time, term-time working, working from home, staggered hours and selfrostering.

An employer shall only refuse an application on one or more of the following specified grounds:

- the burden of additional cost;

- the detrimental effect on ability to meet customer demand;

- inability to re-organise work among existing staff;

- inability to recruit additional staff;

- detrimental impact on quality;

- detrimental impact on performance;

- insufficiency of work during the periods the employee proposes to work;

- planned structural changes; and

- such other grounds as the Secretary of State may specify by regulations. 
There is no requirement that the employer's decision must be reasonably based on one of these grounds, although unreasonable conduct may give rise to liability in ways discussed below (Anderson, 2003: 39).

Furthermore, the application itself requires the employee to explain "what effect, if any, the employee thinks making the change will have on his employer and how, in his/her opinion, any such effect might be dealt with"(Sec 80F(2)(c), Employment Act, 2002).

Williams (2003: 289) argues that this is an extremely onerous burden and that the duty to devise a workable solution to the request ought to fall on "the more sophisticated, highly resourced, organisational skills of employers".

In addition, it is argued that the permissible grounds for refusal provide considerable scope for the employer to refuse requests, tipping the balance too firmly in the employer's favour (Williams, 2003: 290).

\subsection{Procedures for request and complaint}

Having received a request, an employer must meet with the employee within 28 days. At this meeting an employee has the right to be accompanied by a fellow employee. Within 14 days of the date of the meeting an employer must give the employee notice of his/her decision, and where it is a refusal, he/she must state which of the specified grounds it relates to and provide a "sufficient explanation" as to why those grounds apply (Regulation 3207 (Proc Requirements) Sec 5(b)(ii)).

The effect of a successful application is to permanently change the employee's contract. This has significant ramifications and unless an employer agrees to alter the terms in the future, the potential long-term fiscal ramifications will have to be considered at the time of application.

A right to an internal appeal is granted in the Regulations for employees who claim that their employers have either failed to comply with their procedural duties, have based their rejection on incorrect facts; or have failed to base their rejection on a permitted ground.
If the appeal is rejected, the employee has one further avenue in the form of an external appeal before an Employment Tribunal or an Advisory, Conciliation and Arbitration Service (ACAS) arbitrator. They are limited to the considerations above and do not have the power to question the commercial validity of the employer's decision or substitute their own judgement on the business reasons adopted by the employer (Williams, 2003: 290).

The tribunal who finds the employee's complaint to be valid may order compensation of no more than eight weeks pay or make an order for reconsideration of the employee's request.

This is probably the most significant drawback of the provisions (Williams, 2003: 290). There is little deterrence in the penalty. The Trade Union Congress (TUC) lobbied for compensation to be set at a minimum of 52 weeks pay (Anderson 2003: 41).

This legislation has been termed "sound bite" legislation (Anderson 2003: 41) - legislation that gives more by way of the publicity given to it's introduction, than by way of actual redress for harassed parents wishing to challenge unsympathetic managers.

The results of the second flexible working employee survey (Grainger \& Holt, 2005) showed that 71 per cent of women and 60 per cent of men were aware of this right and that almost a quarter of employees who were eligible to make a request had done so in the past two years. In addition, the rate of employer refusal of requests had almost halved since the right was introduced.

A significant extension of this right is contained in the Work and Families Bill, where it is proposed to extend the right to request flexible working arrangements to carers of adults from April 2007. The broad intention is that employees who have carer responsibilities for disabled or sick adults who are unable to care for themselves will have the right to make such a request.

Despite consideration of the right to request flexible working arrangements for parents with older children (i.e. over the age of 6 ), this extension has not been forthcoming in the Bill. This has been criticised by the TUC who, 
although recognising the positive impact of the right to request, advocate for the extension of the right to all carers and a stronger regulatory framework together with more fundamental policy changes in relation to flexible working time in Britain (Fagan, Hegewisch \& Pillinger, 2006: 6).

These rights operate independently of existing employment law rights and an employee may bring an additional claim under the relevant anti-discrimination or unfair dismissal legislation, which provides for greater levels of compensation. This is discussed below.

\subsection{How the right works with other legislation}

The discussion above has outlined the remedy for breach of procedure when requesting flexible working arrangements. The Employment Relations Act (ERA) also provides protection for employees from dismissal or detriment as a result of their application or proposed application for flexible working.

As mentioned above, other legislation may apply offering better redress. There are four types of possible claim:

- Sex Discrimination (direct and indirect) under the Sex Discrimination Act (SDA). This is likely to yield higher compensation and the burden of proof is on the employer once the employee raises a presumption of discrimination. However, reinstatement or reengagement is not available under the SDA. The remedy is compensation, a declaration that there has been discrimination and/or a recommendation to the employer to take specific action to prevent further discrimination occurring which may include a recommendation to agree to the flexible working arrangement requested by the employee. If the employer fails to comply with the award the tribunal can either increase the compensation already awarded or award compensation where none was awarded previously

- Unfair Dismissal can be claimed under the ERA. The remedy is reinstatement, reengagement, a basic award based on a statutory formula relating to a specified number of weeks pay calculated by reference to the number of years worked and the age of the employee, or compensation. It is automatically unfair under Sec 104C to dismiss an employee who has been employed for more than one year if the reason or principal reason is that the employee:

- Made (or proposed to make) an application for flexible working;

- Exercised (or proposed to exercise) a right under the procedure;

- Brought proceedings against the employer for breach of the procedure;

- Alleged the existence of any circumstance which would constitute a ground for bringing such proceedings;

- Exercised his right to accompaniment or for being a companion (this is in terms of the procedural regulations).

- Unlawful detriment under the ERA. An employee has the right not to be subjected to any detriment by any act, or deliberate failure to act, by the employer on the grounds of making or proposing to make an application for flexible working. The remedy is a declaration that there has been a detriment and/or compensation that is just and equitable. If the detriment amounts to a dismissal, an employee should claim unfair dismissal instead.

- A specific claim for breach of a right under the ERA such as the complaint of refusal of an application on impermissible grounds (discussed above). Whether or not a specific remedy exists, a parent can claim the general remedies for sex discrimination, unfair dismissal or detriment set out above.

3

\section{Work/Life Balance: Why would companies adopt family-friendly policies and what are the organisational outcomes?}

There have been two broad types of familyfriendly policies identified (Glass \& Estes, 1997): 
a) policies that substitute for the services of the family caregiver (this includes a workplace nursery or child care subsidy, emergency back-up care arrangements), and

b) policies that give employees greater control over work time through paid leave or flexibility in terms of work schedules or the location of work.

An overview of the literature on organisational involvement in work-life balance is provided diagramatically in Figure 1 and Figure 2 below:

Figure 1

An assessment of organisational considerations of family friendly arrangements

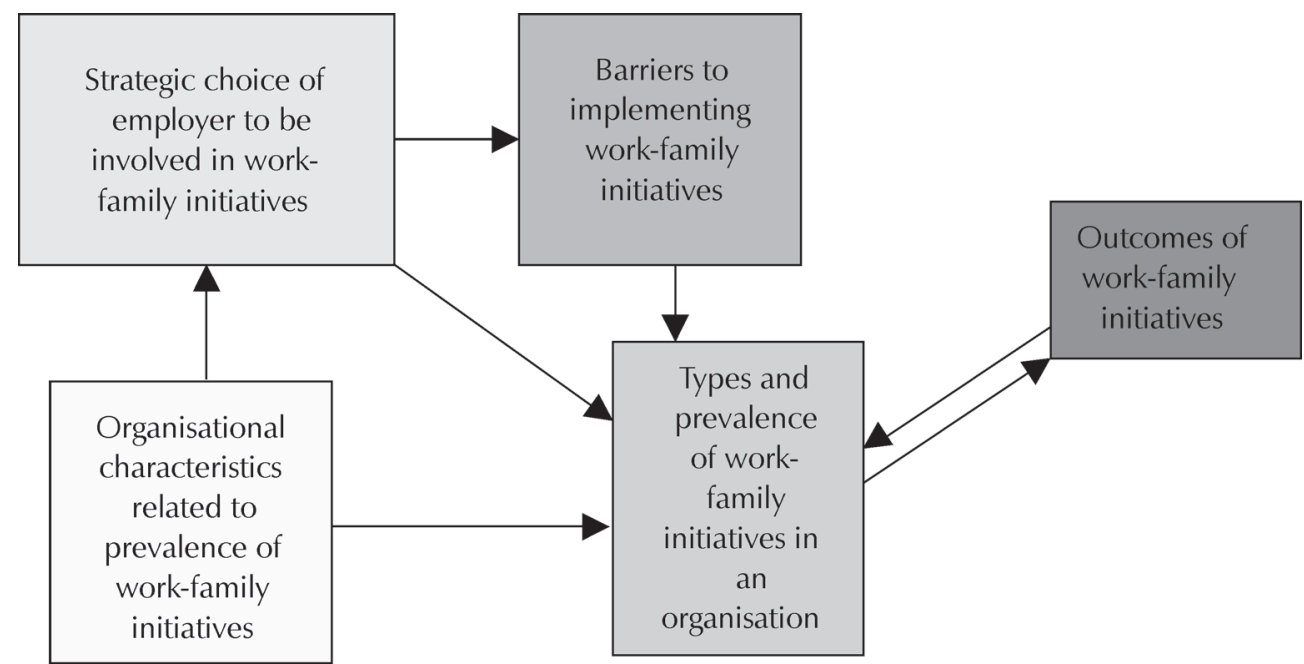

Figure 2 is an elaboration of each of the boxes in Figure 1.

The findings from studies in the literature (as discussed further below) indicate that organisational characteristics (such as size, gender composition - see Figure 2 below) influence employers' decisions on the types and prevalence of family-friendly arrangements, as elaborated in Figure 2 below. The nature of the decision making process itself has also been studied in relation to family-friendly arrangements and analysed within the two theories of strategic choice mentioned in Figure 2.
The rational choice perspective will be influenced by perceived outcomes for the organisation. The literature on work-life balance discusses not only the outcomes to the organisation, but societal and individual outcomes as well.

In addition, barriers have been identified in the literature, negatively affecting the implementation and/or effectiveness of various workfamily arrangements. The barriers are not only organisational, but also individual and societal as elaborated in Figure 2. 


\section{Figure 2}

Details of the boxes in Figure 1.

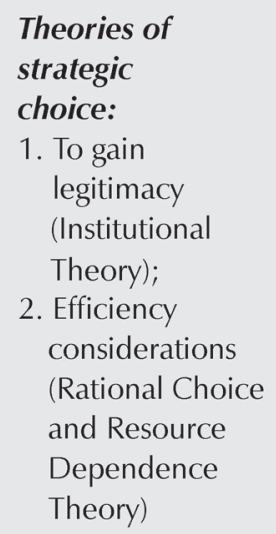

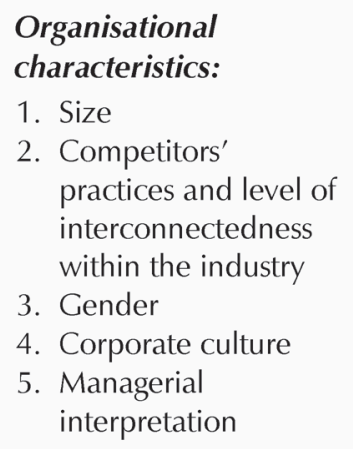

1. Size

2. Competitors' practices and level of interconnectedness within the industry

3. Gender

4. Corporate culture

5. Managerial interpretation

\section{Barriers:}

A: Societal:

- lack of policy

B: Organisational:

- gender role assumptions

- rigid schedules

- lack of management support

- corporate culture

C: Individual:

- Perceived job insecurity
Types of family- friendly arrangements:
1. Maternity/paternity parental leave
2. Childcare provisions
3. Payments to assist parents
4. Flexible work arrangements
5. Short-term leave for family-related purposes

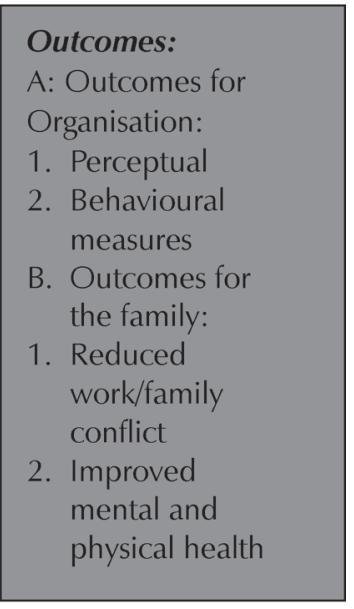

\section{Outcomes:}

A: Outcomes for

Organisation:

1. Perceptual

. Behavioural

measures

Outcomes for

the family:

work/family

Improved

mental and

physical health
In the UK, the Workplace Employee Relations Survey (WERS 98) data results on the extent of flexible working arrangements offered to nonmanagerial employees found that:

- 34 per cent of companies offered parental leave (this was prior to the statutory introduction);

- 27 per cent offered job-sharing;

- 33 per cent offered working at or from home during normal working hours;

- 5 per cent offered a workplace or other nursery or help with child care;

- 24 per cent offered a scheme for time off for emergencies; and
- 27 per cent offered flexitime (Dex, McCulloch \& Smith, 2002: 6).

In the US, the Families and Work Institute conducted a Business Work-Life Survey (Galinsky \& Bond, 1998) in companies with more than 100 employees and found that:

- 68 per cent of firms allow employees to periodically change starting and quitting times;

- 81 per cent allow employees to return to work gradually after childbirth or adoption;

- 55 per cent allow employees to work at home occasionally; 
- 33 per cent allow them to work at home or off-site on a regular basis;

- 9 per cent provide child care at or near the worksite; and

- 5 per cent provide childcare subsidies.

More recently, findings from the Families and Work Institute 2005 National Study of Employers ${ }^{3}$ found that most work-life initiatives offered by employers are being maintained and some expanded. In addition, small employers are significantly more likely to offer flexibility to all or most employees than employers of other sizes. The major obstacle to providing work-life policies, cited by 46 per cent of employers, is cost. Interestingly, supporting employees and their families is not the main reason for introducing these initiatives - nearly 47 per cent of employers reported doing so in order to recruit and retain employees and 25 per cent reported doing so to enhance productivity and commitment.

Two main theoretical perspectives for the reasons why companies adopt family-friendly policies have been identified as:

a) The rational choice perspective which argues that employers will adopt family friendly policies beyond what is legally required of them if the benefits of doing so exceed the costs; and

b) The perspective based on institutional theory, that institutional pressures including the law and social pressures (including the desire to enhance reputation and follow others in the industry group who have adopted these policies) will motivate companies to adopt these policies (Appelbaum, Bailey, Berg \& Kallenberg, 2003: 8).

Studies (initially in North America but more recently in the UK and Australia) focusing on factors associated with the adoption of FWAs and other work-family practices, rather than actual practice and employee use of these initiatives, have found that organisational size, employment sector and economic factors are widely identified as being associated with the adoption of policies (Goodstein, 1994; Ingram \& Simmons, 1995; Milliken, Martins \& Morgan, 1998).

The research suggests that large organisations are more likely to provide formal FWAs than smaller ones; public sector organisations are more likely to develop initiatives than private sector companies; and within the private sector, arrangements are more common in the service and financial sector than construction and manufacturing (Bardoel, Tharenou \& Moss, 1998; Ingram \& Simons, 1995; Morgan \& Milliken, 1992; Wood, 1999; Forth, Lissenburgh, Callender \& Millward, 1997; Hogarth, Hasluck, Pierre, Winterbottom \& Vivian, 2000 in Lewis, 2003: 3).

Organisations with more women managers seem to provide work-family arrangements more often than organisations with women employed mainly in lower skilled jobs (Glass \& Fujimoto, 1995). Organisations with relatively "progressive" employment policies and philosophies, seeking to implement highcommitment management may also be more likely to develop FWAs and other work-family supports (Osterman, 1995).

Other studies have focused on the outcomes of FWAs - i.e does the adoption of FWAs improve productivity, job satisfaction, reduce absenteeism etc? This area is complex ${ }^{4}$ : There is research that concludes that both flexitime and compressed working weeks have positive effects on productivity or self-rated performance, job satisfaction and satisfaction with work schedules but that absenteeism was affected by flexitime only (Baltes, Briggs, Huff, Wright \& Neuman, 1999 in Lewis 2003: 9).

There is research examining whether or not positive outcomes cease with too much flexibility (Baltes et al. 1999 in Lewis 2003: 8).

Organisational culture or climate has been found to be a crucial variable contributing to the outcomes of FWAs (Lewis, 1997, 2001; Lewis, Smithson, Cooper \& Dyer, 2002; Bailyn, 1993; Hochschild, 1997; Friedman and Johnson, 1996; Friend, 1998 in Lewis 2003: 17). 
5

\section{An overview of state intervention in work-family policies and practices:}

Cross-national comparisons typically cluster countries into groups with similar characteristics, the best known being EspingAndersen's three regimes of welfare capitalism:

- social democratic (e.g. the Nordic countries) where the employment of women is expected to be high with a large public sector, generous parental leave policies and extensive use of public or subsidised childcare;

- conservative-corporatist (e.g. the continental European countries) where the employment of women is expected to be lower where women's work has been marginalised and public policy encourages women to stay home with their children; and

- liberal (e.g. the English- speaking countries) where the employment of women is moderate in these market-driven liberal countries (Esping-Anderson in Appelbaum et al., 2003: 19).

The range of policies internationally includes the following:

- Maternity/paternity/parental leave. These policies vary as to the duration of leave, whether or not it is paid and at what level, the leave provisions for fathers, and the safeguarding of employment rights.
- Childcare. These policies vary as to whether childcare assistance is means-tested or free, whether it is available to those who are unemployed to help them into employment, and in terms of who provides the care and how it is funded.

- The provision of direct payments or subsidies to assist parents. These include tax rebates or credits and free or subsidised goods or services.

- Flexible working hours that acknowledge the employees' family responsibilities.

- Short-term leave for family-related purposes, such as the care of sick children, and in some countries other dependents and other persons.

- Anti-discrimination legislation and gender equity in employment practices. This includes legislation that prohibits discrimination in employment on the grounds of gender, family status and relationship status (James, 2002).

There are enormous differences in the nature, level and extent of state intervention in workfamily policies. The histories of the countries with regard to their economies, political systems, approaches to welfare, the concept of the family and gender relations have affected this diversity (James, 2002: 2).

A summary of the range of policy responses for the reconciliation of work and family life is listed below (James, 2002: 3):

\begin{tabular}{|l|l|}
\hline Area & Responses \\
\hline $\begin{array}{l}\text { Level of state } \\
\text { Intervention in } \\
\text { family matters }\end{array}$ & $\begin{array}{l}\text { Belgium, Germany, Luxembourg, France: principle of state intervention in family matters } \\
\text { is widely accepted. } \\
\text { UK, Italy, Spain: state reluctance to intervene unless family members are at risk. }\end{array}$ \\
\hline Funding sources & $\begin{array}{l}\text { Nordic }{ }^{5}, \text { UK, Ireland: benefits funded from taxation. } \\
\text { Belgium, Greece, Italy, Portugal, Spain: insurance- based social security. } \\
\text { Austria, Luxembourg, France, Netherlands: mixed public and employer funding. }\end{array}$ \\
\hline $\begin{array}{l}\text { Devolution from } \\
\text { central to } \\
\text { local } \\
\text { government }\end{array}$ & $\begin{array}{l}\text { Nordic: strong involvement of local government. } \\
\text { Netherlands: administration of benefits through local government. } \\
\text { Italy: local government leadership in the development of family-friendly workplaces. }\end{array}$ \\
\hline
\end{tabular}




\begin{tabular}{|c|c|}
\hline $\begin{array}{l}\text { Involvement of } \\
\text { employers }\end{array}$ & $\begin{array}{l}\text { UK }{ }^{6} \text {, Italy: lack of statutory intervention to require employers to adopt work-family } \\
\text { arrangements. } \\
\text { Netherlands: government expects employers and employees to negotiate work-family } \\
\text { agreements through collective agreements. Government role is to remove barriers and to } \\
\text { 'stimulate' the development of work-family arrangements. } \\
\text { Australia, Canada: strong role of collective bargaining in establishing family-friendly work } \\
\text { arrangements. } \\
\text { France: all employers contribute to the costs of services of young children. }\end{array}$ \\
\hline $\begin{array}{l}\text { Childcare } \\
\text { responsibility }\end{array}$ & $\begin{array}{l}\text { Nordic: substantial system of public childcare with commitment to provide places for all } \\
\text { children over } 12 \text { months. Strong view that caring for young children is a public } \\
\text { responsibility. } \\
\text { Netherlands, Germany: minimal public provision of childcare, combined with strong } \\
\text { public-private sector partnerships. } \\
\text { France, Belguim: universal nursery schooling, extensive out-of-school provision and above } \\
\text { average levels of provision for under } 3 \mathrm{~s} \text {. } \\
\text { Spain: publicly funded services for children } 3-6 \text { years are widely developed as part of } \\
\text { education system. } \\
\text { Australia: education sector-based pre-schooling. Centre-based day care (mainly private } \\
\text { providers) predominates. Informal care very important. }\end{array}$ \\
\hline Employment & $\begin{array}{l}\text { Nordic: emphasis on getting both women and men into (full-time) employment, } \\
\text { irrespective of family status. } \\
\text { Netherlands: individual's right to part-time work. Interventions to reduce barriers to } \\
\text { employment of women. } \\
\text { UK: increasing expectations on sole mothers to enter employment (underpinned by } \\
\text { concerns to keep benefit expenditure down). Married women/mothers fall outside of the } \\
\text { adult worker expectation. } \\
\text { Australia and Canada, Spain: increase in flexible and temporary work to promote } \\
\text { employment and reduce labour costs (ambiguous benefits for gender equity). }\end{array}$ \\
\hline $\begin{array}{l}\text { Statutory, } \\
\text { support for } \\
\text { father role }\end{array}$ & $\begin{array}{l}\text { Netherlands: special father's leave. } \\
\text { EU: widespread adoption of parental leave for either parent. }\end{array}$ \\
\hline $\begin{array}{l}\text { Package } \\
\text { approaches }\end{array}$ & $\begin{array}{l}\text { Nordic: comprehensive package of parental leave, childcare provisions in conjunction } \\
\text { with obligations for citizens to work. }\end{array}$ \\
\hline Gender equity & $\begin{array}{l}\text { Nordic: policies have aim to increase equality between women and men. } \\
\text { Australia: legislation concerning discrimination and human rights has been used to } \\
\text { improve the situation of women. }\end{array}$ \\
\hline
\end{tabular}

\section{6}

\section{Researching work-life balance in South Africa}

There is little or no research investigating why and to what extent employers have introduced family-friendly work provisions in South Africa. Research in South Africa has focused more on labour market flexibility (Horwitz, 1998) or atypical work (Greef \& Nel, 2003; Valodia, 2000) but not in the context work-life balance. In South Africa, flexible work arrangements such as job sharing, in addition to providing an opportunity for women to better combine work and family, "should create additional capacity, especially on the middle to senior management levels, to increase the number of people from the designated groups in posts to these levels, where they are currently underrepresented" (Greeff \& Nel, 2003). It has also been conclusively demonstrated that job sharing is a feasible approach to address layoff and unemployment in South Africa (Ngami, 1999 in Greeff \& Nel, 2003). Given the potential positive spin-offs from certain family-friendly initiatives, to whom should the benefits be offered? 
Apart from employees with childcaring responsibilities, other employees (both male and female) may have caregiving responsibilities that may involve sick or aged family members and to whom family-friendly policies should apply. In South Africa there has been a gradual shift in the model of care of people living with HIV/Aids from hospital care to home-based care (Akintola, 2004). Akintola has found that, in addition to the physical, psychological, social and emotional stress on a caregiver, economic stress is ever present for most caregivers, in part due to a reduction in household income through the caregivers losing their jobs.

There is scope to research the extent to which these unemployed caregivers would remain in some employment, albeit on a 'reduced income' basis, if family-friendly arrangements such as job-sharing or flexi-time were on offer to carers of the infirm or elderly (as per the proposed extension of the UK right to request flexible working arrangements in the Work and Families Bill).

Research in South Africa has concentrated mainly on flexible and atypical working arrangements as efficiency measures rather than tools for enhancing work-life integration.

There is a need in South Africa to examine the issue of state policy regarding work-life balance and to examine the position of other role-players, which would include research into organisational implementation of familyfriendly arrangements and the attention given to the issue by trade unions. Successful policies developed elsewhere are responsive to the particular problems and conditions of that society and cannot simply be applied here without analysis of their relevance, feasibility and suitability for South Africa.

The following factors are useful in the consideration of the development of policies for the reconciliation of work and family life (James, 2002: 7):

- There must be a clear view of what the policy is aiming to achieve.

- If the policy is expected to achieve multiple aims, there needs to be analysis of whether those aims are conflicting, and if so, how a balance is to be achieved.
- A coherent package of policy across parental leave, childcare, taxation, working conditions, employment/training programmes, anti-discrimination etc. appears to be more effective than single policies. A package enables the links between work and family life to be considered, rather than seeing the spheres as separate.

- Policies must look at the effects on both women and men. The experiences of balancing work and family life are markedly different for mothers and fathers. Furthermore, policies need to consider women in their multiple roles as workers, mothers and as contributing to the community.

- The diverse experiences of, and impacts on different groups including low-income families, people with disabilities, the unemployed and people without children must be considered.

- Policies must be challenged to influence organisational cultures and address entrenched attitudes to women's roles.

\section{7 \\ Conclusion}

The integration of paid work with the rest of life needs to be seen as an issue for serious concern, given its link to other social problems facing individuals, families, workplaces and communities. There is a need to change mindsets, and in so doing, strengthen the impact of policy and legislation and to produce new ideas and practices (Lewis, Rapoport \& Gambles, 2003: 17).

In the UK, New Zealand and Australia, cultural inertia rather than the cost of compliance is seen as the main barrier to reform in this area. Employers and managers are simply wedded to standard arrangements, and have not been challenged to rethink their ways (Thompson, 2003: 1807).

The pressure on employers for workplace reform is coming from two quarters: employees who want a better life balance, and civil society, which is demanding that employers internalise 
the social costs that they are intent on exporting from the marketplace (Thompson, 2003: 1806).

It is time to unpack some outdated assumptions and ask some fundamental questions: What are good lives? What kind of societies do we want to live in? How do the ways we integrate the different aspects of our lives affect wider societies? And how does this feed into desires to make societies more democratic, equitable and enjoyable (Lewis et al., 2003: 5)?

\section{Endnotes}

1 However, this is not the only determinant of organisational decision making in this area. Other factors identified in studies on the introduction of flexible working arrangements include strategic business concerns (such as the studies on the relationship between the policies and work related outcomes), local situational variables (such as the size of the business) and human resource strategies (including management attitudes and implementation of the policies). (Lewis, 2003).

2 The main relevant provisions are to be found in Part 8A of the Employment Rights Act 1996 (as inserted by Section 47 of the Employment Act 2002). Important procedural and eligibility issues are dealt with in two sets of regulations - the Flexible Working (Procedural Requirements) Regulations 2002 (SI 3207//2002) and the Flexible Working (Eligibility, Complaints and Remedies) Regulations 2002 (SI 3236/2002).

3 The 2005 National Study of Employers was conducted by Families and Work Institute as a part of the "When Work Works" project, and is funded by the Alfred P. Sloan Foundation. An executive summary and full report of the study are available at www.whenworkworks.org.

4 This is, in part, due to the different dependent variables (such as sales performance, self-rated performance, self-efficacy ratings and supervisor ratings) used in outcome research which makes comparison difficult (Lewis, 2003:8).

5 Sweden, Denmark and Finland.

6 This article was in 2002 prior to the 2003 legislative changes on FWAs in the UK.

\section{References}

1 AKINTOLA, O. (2004) "A gendered analysis of the burden of care on family and volunteer caregivers in Uganda and South Africa”, Executive summary of Phd produced in the Health Economics and HIV/AIDS Research Division UKZN.

2 ANDERSON, L. (2003) "Sound bite legislation: The Employment Act 2002 and new flexible 'rights' for parents", Industrial Law Journal, 32(1): 37-42.

3 APPELBAUM, E.; BAILEY, T.; BERG, P. \& KALLENBERG, A. (2003) "Organisations and the intersection of work and family: A comparative perspective", In Ackroyd, Batt, Thompson and Tolbert (eds.) The Oxford Handbook on Work and Organisation: 52-73, Oxford University Press: New York.

4 DEX, S.; MCCULlOCH, A. \& SMITH, C. (2002) 'Employees' awareness of employer's flexible working arrangements", WP 2/2002, Research Papers in Management Studies, The Judge Institute of Management: University of Cambridge.

5 DI MAGGiO, P. \& POWELL, W. (1983) "The iron cage revisited: Institutional isomorphism and collective rationality in organisational fields", American Sociological Review 48: 147-160.

6 FAGAN, C.; HEGEWISCH, A. \& PILLINGER, J. (2006) "Out of time", Report for the Trade Union Congress: European Work and Employment Research Centre.

7 GLASS, J. \& ESTES, S. (1997) "The family responsive workplace", Annual Review of Sociology, 23: 289-313.

8 GLASS, J. \& FUJIMOTO, T. (1995) “Employer characteristics and provision of family responsive policies”, Work Occupation, 22: 380-411.

9 GOODSTEIN, J. (1994) "Institutional pressures and strategic responses: employer involvement in work-family issues", Academy of Management Journal 37(2): 350-382.

10 GRAINGER, H. \& HOLT, H. (2005) "Results of the second flexible working employee survey", Labour Market Trends, July: 297-302.

11 GREEFF, A. \& NEL, P. (2003) "Employment transformation enhancement in South Africa: Establishing a job-sharing model to promote employment equity", South African Journal of Labour Relations, 27(2): 23-62. 
12 HORWITZ, F; BROSNAN, P. \& WALSH, P. (1998) "Workplace flexibility and labour cost reduction in three countries: A study of small and medium sized businesses", South African Journal of Labour Relations, 22: 26-43.

13 INGRAM, P. \& SIMONS, T. (1995) "Institutional and resource dependence determinants of responsiveness to work-family issues", Academy of Management Journal, 38: 1466-1482.

14 JAMES, B. (2002) "European, Australian and Canadian policies to reconcile paid work and family life", Paper prepared on contract to Ministry of Women's Affairs (NZ), www.mwa.govt.nz.

15 KOOPMANS, I. \& SCHIPPERS, J. (2003) "Female employment and family formation - The institutional context", Paper presented for the joint meeting of MoCho, FENICS, DynSoc and AGIR, Brussels, 18-20 February 2003.

16 LEWIS, S.; RAPOPORT, R. \& GAMBLES, R. (2003) "Reflections on the integration of paid work and the rest of life", Journal of Managerial Psychology 18(8): 829-842.
17 LEWIS, S. (2003) "Flexible working arrangements; implementation, outcomes and management", International Review of Industrial and Organisational Psychology (eds.) C. Cooper and I. Robertson.

18 MILLIKEN, F; MARTINS, L. \& MORGAN, H. (1998) "Explaining organisational responsiveness to work-family issues: The role of human resource executives as issue interpreters", Academy of Management Journal, 41(5): 580-592.

19 OSTERMAN, P. (1995) "Work/family programs and the employment relationship", Administrative Science Quarterly, 40: 681-700.

20 THOMPSON, C. (2003) "The changing nature of employment", Industrial Law Journal, 24: 1793-1815.

21 VALODIA, I. (2000) "Economic policy and women's work in South Africa: overlooking atypical work?" Paper presented at the conference of the International Association for Feminist Economics, Turkey.

22 WILLIAMS, A. (2003) "A critical appraisal of the right to request flexible working arrangements", Business Law Review, 24: 287292. 